\title{
Physicochemical and Organoleptic Properties of Caramel Coated Chhana Confection Incorporated with Mango and Pineapple Powder
}

\author{
Simranjeet Kaur ${ }^{1 *}$, Sunil Kumar ${ }^{2}$ and Ramandeep Kaur ${ }^{3}$ \\ ${ }^{1}$ Division of Livestock Products Technology, NDVSU, F.V.Sc. \& A.H., Jabalpur, M.P, India \\ ${ }^{2}$ Division of Livestock Products Technology, SKUAST, F.V.Sc. \& A.H., R.S. Pura, \\ Jammu, India \\ ${ }^{3}$ Division of Entomology, SKUAST, F.A.O., Chatha, Jammu, India \\ *Corresponding author
}

\section{Key w o r ds \\ Chhana, Mango powder, Pineapple powder, \\ Caramel, Confection, Quality parameters \\ Article Info \\ Accepted: 17 July 2018 Available Online: 10 August 2018}

\section{A B S T R A C T}

The present study was conducted to prepare a designer confection by incorporating different levels of pineapple powder and mango powder $(2 \%, 4 \%$ and $6 \%)$ separately into the chhana base (chhana 95g + milk powder 5g) replacing chhana in formulation. Prepared samples were analysed for various parameters after coating with caramel. No significant ( $p>0.05$ ) difference was recorded in the mean values of moisture, fat, protein, ash, lactose, cholesterol and carbohydrate content in all the mango powder and pineapple powder incorporated treatments as compared to control. $\mathrm{pH}$ value showed a significant $(\mathrm{p}<0.05)$ decreasing trend at $4 \%$ and $6 \%$ level of mango powder and pineapple powder incorporation. Titratable acidity was found to be significantly $(\mathrm{p}<0.05)$ higher in caramel coated chhana confection with addition of mango powder and pineapple powder at $6 \%$ level as compared to control. Water activity increased significantly $(\mathrm{p}<0.05)$ with addition of pineapple powder at $6 \%$ level, however, no significant effect $(\mathrm{p}>0.05)$ was observed on water activity of samples incorporated with mango powder. No significant difference ( $>0.05$ ) was recorded in the mean values of coating loss, cooking yield and weight of coating of mango and pineapple powder treated samples as well as control. Colour analysis was done for all the samples and no significant ( $p>0.05$ ) effect was observed on $L^{*}$ and $a^{*}$ colour values of mango and pineapple powder incorporated samples, however $\mathrm{b}^{*}$ value increased significantly $(\mathrm{p}<0.05)$ at $6 \%$ level of mango powder incorporation as compared to control. On the basis of sensory attributes, most acceptable confection was prepared by incorporation of mango powder and pineapple powder at $4 \%$ level.

\section{Introduction}

Indian dairy market is growing rapidly and as per the reports of Ministry of Agriculture, milk production stands at 155.5 million tonnes during the year 2015-16. Nearly 40-45 per cent of the total milk produced in India is converted into a variety of traditional milk products such as khoa, chhana, paneer, dahi, ghee, shrikhand which plays a significant role in the economic, social, religious and nutritional well-being of the Indian masses 
(Anon, 2014). Chhana is a well-known traditional milk product, used as a base for preparation of wide variety of traditional Indian dairy sweets like rasgolla, sandesh, rasmalai, rajbhog, chhana-murki and chamcham etc.

Dairy based ingredients are natural ingredients which are valued by the confectionery industry for enhancing the flavour, colour, texture and nutritional value particularly the protein profiles in many products including caramels, chocolate coatings, aerated confections and toffee. Confections made with dairy ingredients can help satisfy consumer's sweet cravings with rich, full flavour that contains nutritional value. Commonly used Dairy-based ingredients in confectionery products include whole milk powder, evaporated milk, sweetened condensed milk, fresh cream, butter, anhydrous butterfat, lactose, caseins and whey products (Twomey and Keough, 1998).

Caramel is a medium to dark-brown confectionary product made by heating a variety of sugars. It is a smooth, chewy, sticky confection made by heating sugar and other ingredients until the sugars polymerize and become stick. Process of caramelization involves removal of water from a sugar, proceeding to isomerization and polymerization of the sugars into various highmolecular-weight compounds that contribute to the dark-brown color. Fragmentation reactions result in low-molecular-weight compounds that may be volatile and may contribute to flavor. Usually caramel is used as a flavoring in puddings and desserts, as a filling in bonbons or as a topping for ice cream and custard but the present investigation was based on the use of caramel as coating agent in production of chhana confection using chhana as a base material added with natural fruit powders like pineapple and mango powder. Such confection is expected to increase nutritional profile of sugar based candies and confections.

\section{Material and Methods}

\section{Raw materials}

Fresh cow milk was obtained from the Dairy farm of SKUAST-Jammu. Whole milk powder and food grade crystalline sugar of good quality were purchased from the market of Jammu, mango and pineapple powder manufactured by Sri Nuthatch Nutricare Technologies Pvt. Ltd, Bengaluru, was purchased and stored in plastic airtight container for subsequent use. Caramel was prepared by using ingredients like Amul fresh cream, brown sugar, plain sugar, milk powder, honey, vanilla essence and butter, all purchased from market of Jammu, India.

\section{Methodology of preparation of chocolate coated chhana confection}

\section{Chhana preparation}

It was prepared by following the procedure explained by Bhattacharya et al., (1971). Standardized milk having $4.5 \%$ fat content was heated at $82^{\circ} \mathrm{C}$ for 5 minutes and cooled to $70^{\circ} \mathrm{C}$ followed by coagulation with citric acid (1\% solution), which was added slowly to the milk with continuous stirring until a curd and clear whey separated out. The mixture was allowed to settle down for 10 minutes and the whey was drained out through a muslin cloth. The coagulum so obtained was collected as chhana.

\section{Kneading and ball formation of chhana}

The standardized formulation for chhana confection contained chhana base $(95 \%)$ and whole milk powder (5\%). Different levels of mango powder and pineapple powder $(2 \%$, $4 \%$ and $6 \%$ ) were incorporated separately in 
the standardized formulation of confection, replacing chhana in the formulation. The mixture was then given vigorous working for at least 5-10 minutes manually till all ingredients mixed together in dough form. The dough was moulded into small balls weighing around $12 \mathrm{~g}$ by revolving between palms.

\section{Preparation of sugar syrup}

Sugar solution of $50^{\circ}$ Brix concentration was prepared in water for cooking of chhana balls at low flame. To maintain the $50^{\circ}$ Brix concentration, water was added time to time to compensate for evaporated water.

\section{Cooking of chhana base in sugar syrup}

Sugar syrup was brought to boil in a container and chhana balls were dropped in it. After putting balls in the sugar syrup, the flame was set on low to avoid burning of upper surface of chhana balls. Balls were gently stirred continuously with the help of ladle for 10 minutes. After cooking, chhana balls were removed from sugar syrup and left aside to cool. This was followed by coating of product with caramel in silicon moulds.

\section{Coating of chhana base with caramel}

Caramel was prepared by using ingredients like Amul fresh cream, brown sugar, plain sugar, milk powder, honey, vanilla essence and butter. About 200 gm of cream having 20$25 \%$ fat was heated at low flame in a heavy bottom pan followed by addition of brown sugar, icing sugar (100 g each), milk powder $(30 \mathrm{~g})$ and honey $(70 \mathrm{~g})$. It was stirred continuously on low flame till it became viscous. At this stage thermometer was used and when the temperature of the preparation reached $120^{\circ} \mathrm{C}$, the flame was stopped and small amount of butter and vanilla essence were added for perfect flavouring. Chhana balls were coated with caramel using silicon moulds quickly to avoid solidification of caramel.

\section{Analytical procedures}

\section{Stability of coating material}

Around $50 \mathrm{~g}$ of the sample was taken in a conical flask. Conical flask was shaked continuously using automatic flask shaker (Oracles Automatic Flask Shaker, Delhi, India) for 30 minutes. The samples were removed and the weight of the coating retained in the flask during shaking was recorded (kaji, 2009).

Loss of coating $\%=100(\mathrm{~W} 1-\mathrm{W} 2) / \mathrm{W} 3-\mathrm{W} 2$

Where, W1 = weight of flask with coating material, W2 = Empty weight of flask and W3 $=$ weight of flask and sample.

\section{Weight and thickness of coating}

Ten pieces of caramel coated chhana confection were taken and the dimensions of each were measured by using Vernier calliper (6X6X7 cm, Bexco brand, Chandigarh, India). The weight of each piece was also recorded. After removing the coating of caramel by scrapping, their weight and dimensions were again measured and the difference between the two observations was taken to calculate the weight and thickness of coating (Kaji, 2009).

\section{pH}

$\mathrm{pH}$ of the product was measured soon after products preparation by the method of Keller et al., (1974) with slight modifications. The sample $(10 \mathrm{~g})$ was homogenized with $50 \mathrm{ml}$ distilled water by using pestle and mortar for 1 minute. The $\mathrm{pH}$ of the suspension was recorded by immersing combined glass electrode of digital $\mathrm{pH}$ meter (Systronics Digital pH Meter, Gujrat, India). 


\section{Proximate composition}

The moisture, protein, fat and ash content of caramel coated chhana delights were determined by a standard method using hot air oven (Macro Scientific Works Pvt. Ltd., Delhi, India), kjeldahl assembly (H. L. Scientific Industries, Ambala, India), Soxhlet extraction apparatus (Proxor Group, Chennai, India) and Muffle furnace (Servo Enterprises, Chennai, India), respectively, per AOAC (1995).

\section{Moisture content}

Mashed sample (10g) was transferred in preweight flat bottom aluminum moisture cup, which was transferred to hot air oven at $101 \pm$ $1^{\circ} \mathrm{C}$ and kept for 16-18 hours.

Dried sample was then placed in desiccators having silica gel as desiccant. After 1 hour, the cup containing dried sample was weighed. Moisture content was calculated by applying the following formula:

Moisture $(\%)=\frac{\mathrm{W}_{2}-\mathrm{W}_{3}}{\mathrm{~W}_{2}-\mathrm{W}_{1}} \times 100$

Where, $\mathrm{W}_{1}=$ Weight of empty cup, $\mathrm{W}_{2}=$ weight of cup + sample, $\mathrm{W}_{3}=$ Weight of cup + dried sample

\section{Protein content}

The sample (2-2.2g) was digested using Micro- Kjeldahl digester in presence of digestion mixture which acts as catalyst (sodium sulfate/potassium sulfate: copper sulfate $=5: 1)$ and $40 \mathrm{ml}$ sulphuric acid. Flask was placed in an inclined position and heated gently until solution became clear. The sample was then cooled and distilled water was added to make the volume up to $250 \mathrm{ml}$. The diluted sample $(10 \mathrm{ml})$ was distilled with $10 \mathrm{ml}$ of $40 \% \mathrm{NaOH}$ using Micro-Kjeldahl distillation unit. Steam was distilled over $2 \%$ boric acid $(25 \mathrm{ml})$ containing mixed indicator (1 part $0.2 \%$ methyl red +2 part $0.2 \%$ bromocresol green dye) for 30 minutes. The ammonia trapped in boric acid was determined by titration with $0.1 \mathrm{~N}$ sulphuric acid. The nitrogen $\%$ was calculated using following formula:

(A-B) $\times 0.0014 \times$ Total volume made Nitrogen $(\%)=-------------100$ Weight of sample taken $\times$ Volume of distillate

Where, $\mathrm{A}=$ Titrated value for sample, $\mathrm{B}=$ Titrated value for blank

Protein\% was determined by conversion of nitrogen $\%$ to protein by using conversion factor (6.38) assuming that all the nitrogen in sample was present as protein i.e. Protein $\%=$ $\mathrm{N} \% \times 6.38$.

\section{Fat content}

Fat Content in the sample was extracted in Soxhlet extraction unit. Soxhlet extractor was set with reflux condenser and oil flask which was previously dried and weighed.

Sample (3-4g) was taken into fat free extraction thimble, dried in hot air oven for 6 hours at $100-102^{\circ} \mathrm{C}$ and placed in Soxhlet extraction apparatus. $150 \mathrm{ml}$ of petroleum ether (BP: $60-80^{\circ} \mathrm{C}$ ) was then poured into extraction flask and condenser was joined and placed on electric heater in order to boil the solvent gently. Extraction was carried out for 16 hours. Fat content was calculated by using the following formula:

Fat $(\%)=\frac{\mathrm{W}_{2}-\mathrm{W}_{1}}{\mathrm{~W}_{3}} \times 100$

Where, $\mathrm{W}_{1}=$ Weight of empty oil flask, $\mathrm{W}_{2}=$ Weight of oil flask + Fat, $\mathrm{W}_{3}=$ weight of sample 


\section{Ash content}

The fresh sample in minced form $(5-10 \mathrm{~g})$ was transferred in a pre-weighed crucible and transferred to Muffle furnace at $\left(550^{\circ} \mathrm{C}\right)$ for 4-5 hours. Ashed sample was transferred to desiccator having silica gel as desiccant. After 1 hour, the crucible was weighed. The ash content was calculated by the following formula:

$$
\text { Ash }(\%)=\frac{\text { Weight of ashed sample }}{\text { Weight of sample taken }} \times 100
$$

\section{Total carbohydrate}

The total carbohydrate content of the sample was obtained by difference i.e. Total carbohydrate $(\%)=100-(\%$ Moisture $+\%$ Fat $+\%$ Total protein $+\%$ Ash).

\section{Titratable acidity}

The method as described by AOAC (1995) for cheese was followed to determine the titratable acidity of chhana confection. To $10 \mathrm{~g}$ of sample, distilled water at $40^{\circ} \mathrm{C}$ was added to make the volume up to $105 \mathrm{ml}$.

The contents were shaken vigorously, filtered through whatman no. 1 paper and $25 \mathrm{ml}$ of filtrate representing $2.5 \mathrm{~g}$ of sample was titrated against $0.1 \mathrm{~N}$ sodium hydroxide solution using phenolphthalein solution as indicator.

Result was expressed as lactic acid (\%). Titratable acidity was calculated by using following formula:

Titratable acidity $(\%$ lactic acid $)=0.009 \times \mathrm{V}$ $\times 40$

Where, $\mathrm{V}=\mathrm{ml}$ of $0.1 \mathrm{~N}$ sodium hydroxide solution used in the titration

\section{Assay of total Cholesterol}

Total cholesterol in the lipid extracts was determined by adopting the Tschugaeff reaction as modified by Hanel and Dam (1955). Fifty micro-litre of lipid extract and standard cholesterol solution (1mg in $1 \mathrm{ml}$ chloroform was evaporated to dryness) was taken in separate test tubes to which $2 \mathrm{ml}$ of chloroform, $1 \mathrm{ml}$ of $\mathrm{ZnCl}_{2}$ reagent (reagent was prepared by dissolving $40 \mathrm{~g}$ anhydrous zinc chloride in $153 \mathrm{ml}$ glacial acetic acid at $80^{\circ} \mathrm{C}$ for two hours and filtered through Whatman no. 1 filter paper) and $1 \mathrm{ml}$ of acetyl chloride was added and heated in a water bath at $60^{\circ} \mathrm{C}$ for 10 minutes. The same was also done with blank containing $2 \mathrm{ml}$ of chloroform and $1 \mathrm{ml}$ of each zinc chloride and acetyl chloride at the same time. The colour complex developed was measured by reading optical density at $528 \mathrm{~nm}$ in a spectrophotometer (Systronics UV-VIS Spectrophotometer, Gujrat, India) and expressed as mg per 100g of sample.

\section{Determination of lactose in chhana delights by Lane-Eynon volumetric method}

Determination of lactose content of product was done as per Lane-Eynon volumetric method (Adriano et al., 1934). Triturated sample $(25 \mathrm{~g})$ was taken into a conical flask and it was diluted by adding $200 \mathrm{ml}$ of distilled water. This was followed by addition of $3.75 \mathrm{ml}$ of $10 \%$ acetic acid solution. It was boiled to get a clear filtrate and after cooling it was transferred quantitatively to a $250 \mathrm{ml}$ volumetric flask to make final volume up to mark with distilled water. The burette was filled with this filtrate and $5 \mathrm{ml}$ of each of Fehling solution A and B was taken into 250 $\mathrm{ml}$ conical flask. Then a preliminary titration was made by adding the filtrate containing lactose, from the burette, $1 \mathrm{ml}$ at a time, to the Fehling solution kept boiling till the blue colour changed to red. Then another $10 \mathrm{ml}$ of 
Fehling A and B was taken in another conical flask and the whole volume of the filtrate required previously for reduction of Fehling solution was added to it from burette, so that not more than 0.5 to $1 \mathrm{ml}$ of filtrate is required for complete titration.

Above mixture was heated to boiling and 5 drops of methylene blue indicator was added to the boiling mixture and titration was completed within a total boiling time of 3 minutes by addition of 4 to 6 drops of the filtrate. The end point was indicated by the change of blue colour to colourless supernatant. Lactose content was calculated by the following formula:

Weight of lactose present in $100 \mathrm{ml}$ of milk = $\mathrm{W} / \mathrm{V} \times 250 \times 100 / 25 \mathrm{~g}$

Where, $\mathrm{V}=$ Volume of the filtrate required for complete reduction of $10 \mathrm{ml}$ of Fehling solution and $\mathrm{W}=$ Lactose equivalent in $\mathrm{mg}$ for $\mathrm{v} \mathrm{ml}$.

\section{Colour measurement}

The colour of the chhana confection was measured in the Division of Food and Technology, SKUAST-Chatha, India using a Colorflex colorimeter (Hunter Associated Laboratory, Virginia, USA). Before the test, the instrument was calibrated with standard black and white tile as specified by the manufacturer.

The finely ground sample was placed in the transmission port of the optical unit of a colour difference meter. Light energy from a controlled source was directed through the specimen into an integrating sphere. Phototubes were positioned at the top of the sphere to view the interior of the sphere.

Electrical signals proportional to light quantities present were directed by cable to the measuring unit, where they were read directly as $\mathrm{L}^{*}, \mathrm{a}^{*}$ and $\mathrm{b}^{*}$ colour values.

\section{Water activity (aw)}

Water activity was measured using water activity meter Aqua Lab (Decagon Devices, Washington, USA) in the Division of Food Science and Technology, SKUAST-Chatha, Jammu.

\section{Sensory evaluation}

A trained sensory panel of seven members evaluated the caramel coated chhana confection for various sensory parameters namely colour and appearance, texture, aroma, flavour and overall acceptability. The experiments were replicated three times $(\mathrm{n}=$ 21).

The panel members were scientists and postgraduate scholars of the Faculty of Veterinary sciences, SKUAST- Jammu and conducted the sensory analysis on the basis of nine-point hedonic scale (Pavon, 2003).

Caramel coated chhana confections were served to panellists in random order without disclosing the identity of samples.

\section{Statistical analysis}

The study was conducted in three independent experimental trials, and all the samples were analysed in duplicate $(n=6)$. SPSS version 16.0 software program was used to analyze the data generated by repeating the experiments for all quality parameters.

One-way ANOVA was used to analyze the means of different parameters. Duncan post hoc multiple range test was used to see significant differences between the treatments at 5\% level of significance (Snedecor and Cochran, 1994). 


\section{Results and Discussion}

Proximate composition of caramel coated chhana delights incorporated with mango powder and pineapple powder

The mean values of proximate composition of the caramel coated chhana delights incorporated with different levels of mango powder and pineapple powder $(2 \%, 4 \%$ and $6 \%$ ) separately are presented in table 1 and 2 respectively. No significant difference ( $p>0.05$ ) was recorded in the mean values of moisture, fat, protein, ash, lactose, cholesterol and carbohydrate content in all the mango powder and pineapple powder incorporated treatments as compared to control samples.

Physicochemical parameters of caramel coated chhana delights incorporated with mango powder and pineapple powder

The mean values of physicochemical parameters of the caramel coated chhana delights incorporated with different levels of mango powder and pineapple powder $(2 \%$, $4 \%$ and $6 \%$ ) separately are presented in table 3 and 4 respectively. A significant $(\mathrm{p}<0.05)$ decreasing trend was observed in the $\mathrm{pH}$ of caramel coated chhana confection incorporated with $4 \%$ and $6 \%$ level of mango and pineapple powder, however, no significant effect was observed on $\mathrm{pH}$ value of chhana confection incorporated with $2 \%$ level of mango powder as compared with control samples.

Results were in agreement with Roy et al., (2015) who observed a decrease in $\mathrm{pH}$ with addition of fruit pulps in yoghurt. Santo et al., (2012) also observed reduction in $\mathrm{pH}$ of probiotic yoghurt with addition of passion fruit peel powder. The values for titratable acidity were significantly $(\mathrm{p}<0.05)$ higher at $6 \%$ level of mango and pineapple powder incorporation as compared with control. Water activity of pineapple powder treated samples was found to be significantly higher at $6 \%$ level of incorporation. Monisha et al., (2015) reported a gradual increase in moisture and water activity in biscuits fortified with bamboo shoot powder. The results also agreed with Pongjanta et al., (2006), who reported a significant increase in water activity of bakery products incorporated with pumpkin powder. No significant difference $(p>0.05)$ was recorded in the mean values of coating loss, cooking yield and weight of coating in all the treatments incorporated with mango and pineapple powder as compared with control. Thickness of caramel coating was uneven in case of both mango powder and pineapple powder treated samples and control samples.

This might be attributed to quick solidifying nature of caramel and thus coating was difficult to control. Colour analysis for all the four treatments was done and from the analysis it was observed that no significant ( $p>0.05$ ) effect was observed for $\mathrm{L}^{*}$ and $\mathrm{a}^{*}$ colour values of mango powder and pineapple powder incorporated chhana confection whereas $b^{*}$ value increased significantly with incorporation of mango powder at $6 \%$ level as compared to control. This might be due to bright colour of the product as well as orangish-yellow appearance of the chhana base incorporated with mango and pineapple powder. Similar findings were observed in chhana jalebi and Khoa jalebi by Panneerselvam and Ramanathan (2015) and Pagote and Rao (2012).

\section{Sensory attributes of caramel coated chhana delights incorporated with mango powder and pineapple powder}

The mean values of various sensory parameters of the caramel coated product incorporated with different levels of mango powder and pineapple powder $(2 \%, 4 \%$ and $6 \%$ ) are presented in table 4,5 and 6. 
Table.1 Effect of different levels of mango powder on the proximate composition of caramel coated chhana confection (Mean $\pm \mathrm{SE})^{*}$

\begin{tabular}{|l|c|c|c|c|}
\hline & \multicolumn{4}{|c|}{ Levels of incorporation (\%) } \\
\hline Parameters & Control & T1 & T2 & T3 \\
\hline Moisture (\%) & $18.14 \pm 0.68$ & $18.71 \pm 0.54$ & $20.12 \pm 0.58$ & $20.52 \pm 0.44$ \\
\hline Fat (\%) & $16.76 \pm 0.29$ & $16.37 \pm 0.41$ & $15.90 \pm 0.55$ & $15.69 \pm 0.49$ \\
\hline Protein (\%) & $12.84 \pm 0.42$ & $12.61 \pm 0.55$ & $12.24 \pm 0.63$ & $11.94 \pm 0.40$ \\
\hline Ash (\%) & $0.79 \pm 0.04$ & $0.83 \pm 0.05$ & $0.88 \pm 0.03$ & $0.95 \pm 0.07$ \\
\hline Lactose (\%) & $2.65 \pm 0.38$ & $2.48 \pm 0.48$ & $2.19 \pm 0.31$ & $2.07 \pm 0.36$ \\
\hline Cholesterol (mg/100g) & $18.98 \pm 1.12$ & $18.84 \pm 1.14$ & $18.66 \pm 1.68$ & $18.31 \pm 1.75$ \\
\hline Carbohydrate (\%) & $48.80 \pm 0.36$ & $48.95 \pm 0.51$ & $48.61 \pm 0.65$ & $48.82 \pm 0.67$ \\
\hline
\end{tabular}

$($ Control $)=5 \mathrm{~g}$ milk powder $+95 \mathrm{~g}$ chhana base

(T1) $2 \mathrm{~g}$ mango powder $+5 \mathrm{~g}$ milk powder $+93 \mathrm{~g}$ chhana base; $(\mathrm{T} 2) 4 \mathrm{~g}$ mango powder $+5 \mathrm{~g}$ milk powder $+91 \mathrm{~g}$ chhana base; (T3) $6 \mathrm{~g}$ mango powder $+5 \mathrm{~g}$ milk powder $+89 \mathrm{~g}$ chhana base

Table.2 Effect of different levels of pineapple powder on the proximate composition of caramel coated chhana delights $(\text { Mean } \pm \mathrm{SE})^{*}$

\begin{tabular}{|l|c|c|c|c|}
\hline & \multicolumn{4}{|c|}{ Levels of incorporation (\%) } \\
\hline Parameters & Control & T1 & T2 & T3 \\
\hline Moisture (\%) & $19.09 \pm 0.57$ & $19.26 \pm 0.37$ & $19.42 \pm 0.45$ & $20.15 \pm 0.72$ \\
\hline Fat (\%) & $16.25 \pm 0.51$ & $16.14 \pm 0.49$ & $16.02 \pm 0.46$ & $15.96 \pm 0.41$ \\
\hline Protein (\%) & $12.75 \pm 0.30$ & $12.69 \pm 0.46$ & $12.39 \pm 0.76$ & $12.20 \pm 0.58$ \\
\hline Ash (\%) & $0.76 \pm 0.01$ & $0.80 \pm 0.03$ & $0.84 \pm 0.03$ & $0.90 \pm 0.08$ \\
\hline Lactose (\%) & $2.70 \pm 0.28$ & $2.51 \pm 0.38$ & $2.19 \pm 0.30$ & $2.10 \pm 0.33$ \\
\hline Cholesterol (mg/100g) & $17.89 \pm 1.32$ & $17.62 \pm 1.41$ & $17.25 \pm 1.75$ & $17.09 \pm 1.44$ \\
\hline Carbohydrate (\%) & $48.41 \pm 0.56$ & $48.57 \pm 0.69$ & $49.12 \pm 0.50$ & $48.62 \pm 0.37$ \\
\hline
\end{tabular}

$($ Control $)=5 \mathrm{~g}$ milk powder $+95 \mathrm{~g}$ chhana base

(T1) $2 \mathrm{~g}$ pineapple powder $+5 \mathrm{~g}$ milk powder $+93 \mathrm{~g}$ chhana base; (T2) $4 \mathrm{~g}$ pineapple powder $+5 \mathrm{~g}$ milk powder $+91 \mathrm{~g}$ chhana base; (T3) $6 \mathrm{~g}$ pineapple powder $+5 \mathrm{~g}$ milk powder $+89 \mathrm{~g}$ chhana base

Table.3 Effect of different levels of mango powder on the physicochemical parameters of caramel coated chhana delights $(\text { Mean } \pm \mathrm{SE})^{*}$

\begin{tabular}{|c|c|c|c|c|}
\hline \multicolumn{5}{|c|}{ Levels of incorporation (\%) } \\
\hline Parameters & Control & $\mathrm{T} 1$ & $\mathrm{~T} 2$ & $\mathrm{~T} 3$ \\
\hline $\mathrm{pH}$ & $6.75 \pm 0.09^{\mathrm{a}}$ & $6.68 \pm 0.06^{\mathrm{a}}$ & $6.33 \pm 0.03^{b}$ & $6.13 \pm 0.09^{b}$ \\
\hline Titratable acidity (\%) & $0.278 \pm 0.006^{b}$ & $0.285 \pm 0.005^{\mathrm{ab}}$ & $0.291 \pm 0.006^{\mathrm{ab}}$ & $0.298 \pm 0.004^{\mathrm{a}}$ \\
\hline Water activity & $0.845 \pm 0.002$ & $0.848 \pm 0.009$ & $0.859 \pm 0.005$ & $0.863 \pm 0.005$ \\
\hline Coating Loss (\%) & $0.161 \pm 0.004$ & $0.166 \pm 0.006$ & $0.168 \pm 0.004$ & $0.173 \pm 0.008$ \\
\hline Cooking yield (without coating) $(\%)$ & $83.25 \pm 0.65$ & $83.52 \pm 0.76$ & $84.12 \pm 0.63$ & $84.74 \pm 0.58$ \\
\hline Wt of coating $(\mathrm{g})$ & $10.65 \pm 0.33$ & $10.09 \pm 0.50$ & $10.13 \pm 0.46$ & $10.45 \pm 0.35$ \\
\hline Mean Thickness of coating (cm) & $0.718 \pm 0.032^{a}$ & $0.598 \pm 0.027^{b}$ & $0.600 \pm 0.015^{b}$ & $0.645 \pm 0.018^{b}$ \\
\hline Colour characteristics $(\mathbf{L}) *$ & $30.71 \pm 0.47$ & $31.39 \pm 0.50$ & $31.66 \pm 0.54$ & $31.87 \pm 0.50$ \\
\hline$(\mathbf{a}) *$ & $6.59 \pm 0.24$ & $6.23 \pm 0.23$ & $6.20 \pm 0.25$ & $6.16 \pm 0.25$ \\
\hline$(b) *$ & $16.02 \pm 0.34^{b}$ & $16.45 \pm 0.45^{\mathrm{ab}}$ & $16.52 \pm 0.72^{a b}$ & $17.88 \pm 0.57^{\mathrm{a}}$ \\
\hline
\end{tabular}

$($ Control $)=5 \mathrm{~g}$ milk powder $+95 \mathrm{~g}$ chhana base

(T1) $2 \mathrm{~g}$ mango powder $+5 \mathrm{~g}$ milk powder $+93 \mathrm{~g}$ chhana base; $(\mathrm{T} 2) 4 \mathrm{~g}$ mango powder $+5 \mathrm{~g}$ milk powder $+91 \mathrm{~g}$ chhana base; (T3) $6 \mathrm{~g}$ mango powder $+5 \mathrm{~g}$ milk powder $+89 \mathrm{~g}$ chhana base 
Table.4 Effect of different levels of pineapple powder on the physicochemical parameters of caramel coated chhana delights $(\text { Mean } \pm \mathrm{SE})^{*}$

\begin{tabular}{|c|c|c|c|c|}
\hline \multicolumn{5}{|c|}{ Levels of incorporation (\%) } \\
\hline Parameters & Control & $\mathrm{T} 1$ & $\mathrm{~T} 2$ & T3 \\
\hline pH & $6.68 \pm 0.10^{\mathrm{a}}$ & $6.31 \pm 0.08^{\mathrm{ab}}$ & $6.16 \pm 0.16^{b}$ & $5.88 \pm 0.18^{b}$ \\
\hline Titratable acidity (\%) & $0.274 \pm 0.005^{b}$ & $0.286 \pm 0.004^{\mathrm{ab}}$ & $0.291 \pm 0.004^{\mathrm{ab}}$ & $0.301 \pm 0.008^{\mathrm{a}}$ \\
\hline Water activity & $0.850 \pm 0.009^{b}$ & $0.846 \pm 0.010^{b}$ & $0.852 \pm 0.007^{b}$ & $0.864 \pm 0.002^{\mathrm{a}}$ \\
\hline Coating Loss (\%) & $0.160 \pm 0.009$ & $0.163 \pm 0.011$ & $0.171 \pm 0.009$ & $0.178 \pm 0.005$ \\
\hline Cooking yield (without coating) (\%) & $84.28 \pm 0.42$ & $84.41 \pm 0.51$ & $84.61 \pm 0.70$ & $85.22 \pm 0.37$ \\
\hline Wt of coating $(\mathrm{g})$ & $10.12 \pm 0.28$ & $9.87 \pm 0.49$ & $10.04 \pm 0.31$ & $10.17 \pm 0.32$ \\
\hline Mean Thickness of coating $(\mathrm{cm})$ & $0.631 \pm 0.034^{\mathrm{a}}$ & $0.580 \pm 0.016^{\mathrm{ab}}$ & $0.546 \pm 0.026^{b}$ & $0.577 \pm 0.032^{a b}$ \\
\hline Colour characteristics $(\mathrm{L}) *$ & $31.22 \pm 0.33$ & $31.34 \pm 0.59$ & $31.39 \pm 0.38$ & $31.57 \pm 0.45$ \\
\hline (a)* & $6.42 \pm 0.29$ & $6.30 \pm 0.17$ & $6.08 \pm 0.34$ & $6.00 \pm 0.20$ \\
\hline (b)* & $18.18 \pm 0.21^{b}$ & $18.28 \pm 0.17^{b}$ & $20.52 \pm 0.22^{a}$ & $20.88 \pm 0.24^{\mathrm{a}}$ \\
\hline
\end{tabular}

$($ Control $)=5 \mathrm{~g}$ milk powder $+95 \mathrm{~g}$ chhana base

(T1) $2 \mathrm{~g}$ pineapple powder $+5 \mathrm{~g}$ milk powder $+93 \mathrm{~g}$ chhana base; $(\mathrm{T} 2) 4 \mathrm{~g}$ pineapple powder $+5 \mathrm{~g}$ milk powder $+91 \mathrm{~g}$ chhana base; (T3) $6 \mathrm{~g}$ pineapple powder $+5 \mathrm{~g}$ milk powder $+89 \mathrm{~g}$ chhana base

Table.5 Effect of different levels of mango powder on the sensory parameters of caramel coated chhana delights (Mean \pm SE)

\begin{tabular}{|l|c|c|c|c|}
\hline \multicolumn{4}{|c|}{ Levels of incorporation (\%) } & T2 \\
\hline Sensory parameters & Control & T1 & 73 \\
\hline Colour and appearance & $7.12 \pm 0.12$ & $7.23 \pm 0.16$ & $7.52 \pm 0.21$ & $7.59 \pm 0.15$ \\
\hline Texture & $6.83 \pm 0.18^{\mathrm{a}}$ & $6.78 \pm 0.19^{\mathrm{a}}$ & $6.88 \pm 0.15^{\mathrm{a}}$ & $5.66 \pm 0.15^{\mathrm{b}}$ \\
\hline Aroma & $8.11 \pm 0.17$ & $8.33 \pm 0.14$ & $8.41 \pm 0.17$ & $8.44 \pm 0.12$ \\
\hline Flavour & $7.57 \pm 0.15^{\mathrm{b}}$ & $7.42 \pm 0.16^{\mathrm{b}}$ & $8.35 \pm 0.15^{\mathrm{a}}$ & $8.47 \pm 0.14^{\mathrm{a}}$ \\
\hline Overall acceptability & $7.90 \pm 0.15$ & $8.02 \pm 0.17$ & $7.92 \pm 0.19$ & $7.97 \pm 0.18$ \\
\hline
\end{tabular}

$($ Control $)=5 \mathrm{~g}$ milk powder $+95 \mathrm{~g}$ chhana base

(T1) $2 \mathrm{~g}$ mango powder $+5 \mathrm{~g}$ milk powder $+93 \mathrm{~g}$ chhana base; $(\mathrm{T} 2) 4 \mathrm{~g}$ mango powder $+5 \mathrm{~g}$ milk powder $+91 \mathrm{~g}$ chhana base; (T3) $6 \mathrm{~g}$ mango powder $+5 \mathrm{~g}$ milk powder $+89 \mathrm{~g}$ chhana base

Table.6 Effect of different levels of pineapple powder on the sensory parameters of caramel coated chhana delights $(\text { Mean } \pm \mathrm{SE})^{*}$

\section{Levels of incorporation (\%)}

\begin{tabular}{|l|c|c|c|c|}
\hline Sensory parameters & Control & T1 & T2 & T3 \\
\hline Colour and Appearance & $7.61 \pm 0.12$ & $7.56 \pm 0.13$ & $7.73 \pm 0.19$ & $7.70 \pm 0.15$ \\
\hline Texture & $6.23 \pm 0.12$ & $6.28 \pm 0.11$ & $6.42 \pm 0.13$ & $6.07 \pm 0.12$ \\
\hline Aroma & $7.21 \pm 0.17$ & $7.38 \pm 0.17$ & $7.40 \pm 0.19$ & $7.61 \pm 0.15$ \\
\hline Flavour & $7.19 \pm 0.14^{\mathrm{c}}$ & $7.26 \pm 0.12^{\mathrm{bc}}$ & $7.69 \pm 0.17^{\mathrm{ab}}$ & $7.88 \pm 0.21^{\mathrm{a}}$ \\
\hline Overall acceptability & $7.40 \pm 0.16$ & $7.23 \pm 0.17$ & $7.71 \pm 0.19$ & $7.46 \pm 0.20$ \\
\hline
\end{tabular}

$($ Control $)=5 \mathrm{~g}$ milk powder $+95 \mathrm{~g}$ chhana base

(T1) $2 \mathrm{~g}$ pineapple powder $+5 \mathrm{~g}$ milk powder $+93 \mathrm{~g}$ chhana base; $(\mathrm{T} 2) 4 \mathrm{~g}$ pineapple powder $+5 \mathrm{~g}$ milk powder $+91 \mathrm{~g}$ chhana base; (T3) $6 \mathrm{~g}$ pineapple powder $+5 \mathrm{~g}$ milk powder $+89 \mathrm{~g}$ chhana base 
No significant $(p>0.05)$ effect was observed on colour and appearance, aroma and overall acceptability scores of mango powder and pineapple powder incorporated confection whereas textural scores of caramel coated chhana confection decreased significantly $(p<0.05)$ with incorporation of mango powder at $6 \%$ level as compared to control samples. This could be due to increase in moisture content resulting in slight spreading of product in sugar syrup while cooking. Kulkarni and Joshi (2013) also observed a similar decrease in textural scores with increase in level of papaya powder beyond $2.5 \%$ in biscuits. Flavour scores increased significantly in chhana confection with incorporation of mango powder and pineapple powder at $4 \%$ and $6 \%$ as compared to control. Pravin and Sanita (2017) also reported higher scores for flavour of biscuits incorporated with $6 \%$ mandarin peels powder.

\section{Acknowledgements}

The authors acknowledge the financial support and infrastructure facilities provided by Sher-e-Kashmir university of Agricultural Sciences and Technology, Jammu required for the conduct of research work.

Based on the physico-chemical and sensory characteristics, It may be concluded that pineapple and mango powder could be successfully utilized for the preparation of caramel coated chhana confection. Although, coating of caramel was difficult to control and significant difference was found in the thickness of caramel coating owing to quick solidifying nature of the caramel. On the basis of sensory quality, use of mango and pineapple powder at level of $6 \%$ did not show any beneficial effect as the texture of the confection disintegrated while cooking in sugar syrup at $50^{\circ}$ Brix concentration. It may be concluded that most acceptable quality chhana confection was prepared by using $4 \%$ pineapple and mango powder because of its positive effect on sensory attributes like colour and appearance, flavour, aroma and overall acceptability. Thus pineapple and mango powder up to $4 \%$ level could be very well utilized to prepare caramel coated chhana confection.

\section{References}

A.O.A.C. 1995. Official methods of analysis $\left(16^{\text {th }}\right.$ ed.) Association of official Agricultural Chemists, Washington, DC.

Adriano, F. T., Oliveros, S., B. and Miranda, L. G. 1934. The Lane-Eynon volumetric method for the determination of lactose in milk. The Philippine Journal of Science. 54: 83.

Anon. 2014. Milk production in India (http://www.nddb.org/English/Statistics/ Pages/ Milk-Production.aspx).

Hanel, H. K. and Dam, M. 1955. Determination of small amounts of total cholesterol by the Tschugaeff reaction with a note on the determination of lathosterol. Acta Chemica Scandinavica. 9 (4): 677-682.

Kaji, P. 2009. Process development for production of chocolate chhana murki. Doctoral dissertation, NDRI, Karnal, India.

Keller, J. E., Skelley, G. C. and Acton, J. C. 1974. Effect of meat particle size and casing diameter on summer sausage properties during drying. Journal of Milk Food Technology. 37: 297-300.

Kulkarni, A. S. and Joshi, D. C. 2013. Effect of replacement of wheat flour with pumpkin powder on textural and sensory qualities of biscuit. International Food Research Journal. 20 (2): 587-591.

Ministry of Agriculture. 2015-16. Annual report. Department of animal 
husbandry, dairying \& fisheries, Government of India New Delhi.

Monisha, C., Badwaik, L.S., Borah, P.K., Sit, N. and Deka, S.C. 2015. Influence of bamboo shoot powder fortification on physico-chemical, textural and organoleptic characteristics of biscuits", Journal of food science and technology. 52 (10): 6742-6748.

Pagote, C. N. and Rao, K. J. 2012. Khoa jalebi, a unique traditional product of central India. Indian Journal of Traditional Knowledge. 11(1): 96-102.

Panneerselvam, G. and Ramanathan, A. 2015. Studies on shelf life enhancement of chhana jalebi-a traditional sweet. Carpathian Journal of Food Science \& Technology. 7(4): 48-6.

Pavon, N. R. 2003. Sensory characteristics of flavored milk candies. Master's dissertation, Louisiana State University, U.S.A.

Pongjanta, J., Naulbunrang, A., Kawngdang, S., Manon, T. and Thepjaikat, T. 2006. Utilization of pumpkin powder in bakery products", Songklanakarin
Journal of Science and Technology. 28 (1): 71-79.

Pravin, O. and Sanita, T. 2017. Quality evaluation of biscuit incorporated with mandarin peel powder. Scientific Study \& Research. 18 (1): 19.

Roy, D. K. D., Saha, T., Akter, M., Hosain, M., Khatun, H. and Roy, M. C. 2015 Quality Evaluation of Yogurt Supplemented with Fruit Pulp (Banana, Papaya, and Water Melon). International Journal of Nutrition and Food Sciences. 4 (6): 695-699.

Santo, D. E., Perego, P., Converti, A., Oliveira, M. N. 2012. Influence of milk type and addition of passion fruit peel powder on fermentation kinetics, texture profile and bacterial viability in probiotic yoghurts. LWT-Food Science and Technology. 47(2): 393-399.

Snedecor, G. W. and Cochran, W.G. 1994. Statistical Methods. (6th Ed.). Oxford and IBH Publishing, New Delhi, India.

Twomey, M. and Keogh, M. K. 1998. Milk powder in chocolate. Farm and Food, 8: 9-11.

\section{How to cite this article:}

Simranjeet Kaur, Sunil Kumar and Ramandeep Kaur. 2018. Physicochemical and Organoleptic Properties of Caramel Coated Chhana Confection Incorporated with Mango and Pineapple Powder. Int.J.Curr.Microbiol.App.Sci. 7(08): 3110-3120.

doi: https://doi.org/10.20546/ijcmas.2018.708.332 